Article

\title{
The Liturgical Use of the Organ in the Sixteenth Century: the Judgments of Cajetan and the Dominican Order
}

\section{Michael O’Connor}

St Michael's College, University of Toronto, 81 St Mary’s Street, Toronto, M5S 1J4, Canada;

E-Mail: michael.oconnor@utoronto.ca

Received: 10 June 2014; in revised form: 3 July 2014 / Accepted: 10 July 2014 /

Published: 13 August 2014

\begin{abstract}
This paper explores the liturgical use of the organ in the sixteenth century according to the judgments of Tommaso de Vio, Cajetan (1469-1534) and the Dominicans. In particular, it asks the question: In worship, is solo organ music capable of conveying a specific meaning or a particular text (as seemed to be expected in alternatim practice)? The Dominican sources show an increasingly skeptical attitude, with a consequent tendency to limit the organ's role in worship. The implication of this study is that organ alternatim did not fall out of favor (with the Dominicans at least) because it failed to carry out the job it was given in the fourteenth and fifteenth centuries, but because it could not do the new job is was given in the sixteenth century. Organ alternatim made sense in a gothic worldview, but less so under the influence of renaissance humanism. While these Dominicans accepted the use of the organ, they did so with great concern at the potential influx of secular music into worship, since secular melodies and rhythms, even without their original words, bring multiple inappropriate associations. To remedy this, various strategies were used to harness instrumental music to text.
\end{abstract}

Keywords: Cajetan; Dominican order; organ; alternatim; Renaissance

\section{Introduction}

The book of blessings issued by the French Catholic Bishops in 1988 includes a rite for the blessing of an organ. The rite begins with an unaccompanied hymn, readings, and prayers, after which the celebrant blesses and incenses the organ, which has yet to play a note. The next section is entitled, "Le chant de l'orgue” ([1], p. 339): while all remain silent, the celebrant calls on the organ to "awake and 
intone the praise of God, Creator and Father." The organist is instructed to respond with an improvisation that illustrates this invitation. Subsequent invitations ask the organ to extol Jesus Christ, to sing [of] the Holy Spirit, and to proclaim glory to the Trinity; again the organist improvises in response. Both the invitations and the improvisations rest on the assumption that the organ is capable of producing music that means something, that conveys specific ideas, even textual content. The organ is expected to sing, analogously to the way a human being sings, and those who hear are expected to understand and be edified. This is not a new view; indeed, it is one with a long and controversial history. For some, music has a "secret kinship" with the affections of the soul, so even un-texted music can serve a devotional purpose; for others, the sole job of all sacred music is to pour sacred words into the ears of the faithful-without a text, music is nothing but sound, fleeting and ephemeral ([2], pp. 33-37). My aim in this paper is to explore one specific contribution to this discussion: the liturgical use of the organ in the sixteenth century according to the judgments of Tommaso de Vio (1469-1534), known as Cajetan (from his birth place, Gaeta), and the contemporary regulations of the order to which he belonged, the Order of Preachers, or Dominicans.

There are several specific advantages to this focus. First, during this period, the question is a live one, on account of humanist theories of language and Reformation attitudes to worship. Second, as we shall see shortly, liturgical organ music at this time was usually closely allied to specific texts. This makes it a particularly instructive testing ground for examining the relationship between words and music. In addition, third, in Cajetan, we encounter one of the most interesting and influential thinkers of his time. Tommaso de Vio led a long and active life of scholarly, controversial, pastoral, and diplomatic activities. The best known of these are his defense of the papacy against the conciliarists (1511-12) [3], his attempt to discipline the young Augustinian friar Martin Luther (Augsburg, 1518) [4], his lengthy commentary on each part of Aquinas's Summa Theologiae (1507, 1511, 1517, 1520) [5], and the commentaries on the Bible produced during the final decade of his life [6]. Cajetan also played a significant role in the administration of his order though the first decades of the sixteenth century, a period of intense intellectual and spiritual renewal for the Dominicans. In June 1501, he was called to Rome to take up the post of Procurator General, the order's representative in its dealings with the papacy and the Roman curia. At the General Chapter in 1508, he was elected Master General. After he was made a cardinal in 1517 (and bishop), a new Master General was elected at the General Chapter of 1518. Toward the end of his life, Cajetan was given the role of Cardinal Protector of the Order ([7], pp. 31-33). During Cajetan's lifetime, and particularly during the period of his generalate, the Dominican order established important ground rules with respect to liturgical organ music [8]. Taken together, Cajetan's writings and the Dominican regulations provide a consistent point of view.

This paper will consider the question: In worship, is solo organ music capable of conveying a specific meaning or a particular text (as is assumed in the French rite of blessing)? Broadly, speaking, what the various Dominican sources show is an increasingly sceptical attitude, with a consequent tendency to limit the organ's role in worship. Of course, this paper is about the thinking of certain churchmen about certain musical performance practices (described briefly in the following section); it is not a study of the details of such practices, for which a different set of sources would need to be scrutinized; from the repetition of a number of prohibitions, we can assume that there was a significant distance between the thinking and the practice. 


\section{Alternatim}

For many centuries, the liturgical recitation of longer chants and psalms entailed the distribution of text among two sets of forces: in some cases, a cantor would sing the odd-numbered verses, while the rest of the choir would sing the even-numbered verses. In other cases, the left side of the choir would alternate with the right. Here "choir" typically means a monastic community present in the choir stalls, as distinct both from cantors (who led the singing) and from the "people" (in the nave of the church). For a monk or nun, "joining in” with the liturgy required the verbal enunciation of no more than half the text; the individual was part of a greater whole, a single voice formed of many different voices. On special occasions, one half could be sung in vocal polyphony (perhaps improvised by experiences cantors) [9]. This was one of a number of ways in which the liturgy was made more elaborate, more festive, more richly symbolic to mark the important days in the calendar-together with special sermons, vestments, candles, processions, and the like. By the fourteenth century, the practice had arisen of employing the organ as one of the alternating partners in the chant, again to add to the dignity of festal days. The organ would "sing" half the text, and the choir would sing the other half in alternation. ${ }^{1}$ All of the various performance practices described above are known as alternatim; in this article, I shall be concentrating on the alternation of organ and choir. For example, in the Magnificat, the Gospel canticle for Vespers (Evening Prayer), the organ would play the first "verset," the singers would sing the second, then the organ would play the third, and so on, as follows:

Organ: 1. Magnificat anima mea Dominum.

Singers: 2. Et exultavit spiritus meus in Deo salutari meo.

Organ: 3. Quia respexit humilitatem ancillae suae: Ecce enim ex hoc beatam me dicent omnes generationes.

Singers: 4. Quia fecit mihi magna qui potens est: et sanctum nomen eius.

Organ: 5. Et misericordia eius a progenie in progenie timentibus eum.

Singers: $\quad$ 6. Fecit potentiam in brachio suo: dispersit superbos mente cordis sui.

Organ: 7. Deposuit potentes de sede; et exaltavit humiles.

Singers: $\quad$ 8. Esurientes implevit bonis: et divites dimisit inanes.

Organ: 9. Suscepit Israel, puerum suum, recordatus misericordiae suae.

Singers: $\quad$ 10. Sicit locutus est ad patres nostros, Abraham et semini eius in saecula.

Organ: $\quad$ 11. Gloria Patri et Filio et Spiritui Sancto,

Singers: $\quad$ 12. Sicut erat in principio et nunc et semper, et in saecula saeculorum. Amen.

The organ versets would be based on the music that would have been sung had the singers sung the whole chant as they did on less solemn days. Often this music is found in slow sustained notes in the left hand of the score (i.e., a cantus firmus), accompanied by more intricate counterpoint in the right

1 It is possible that Dante has just such a form of singing in mind at the end of Purgatorio IX, 139-145: "Io mi rivolsi attento al primo tuono, / e ‘Te Deum laudamus' mi parea / udire in voce mista al dolce suono. / Tale imagine a punto mi rendea / ciò ch'io udiva, qual prender si suole / quando a cantar con organi si stea; / ch'or sì or no s'intendon le parole”. (In Longfellow's translation: “At the first thunder-peal I turned attentive / And Te Deum laudamus seemed to hear / In voices mingled with sweet melody. / Exactly such an image rendered me / That which I heard, as we are wont to catch, / When people singing with the organ stand; / For now we hear, and now hear not, the words.”) 
hand. It was normal practice for the organ to take the first verset, thereby establishing the pitch and mode ahead of the singers' entry in verse two. ${ }^{2}$ In organ alternatim, then, about half of the text is not actually sung aloud, but is conveyed solely by the sound of the organ. It was understood, at least initially, that the text was not "missing": it was "sung" by the organ, in a manner proper to the organ, and it was identified by the associated chant tone or melody, and from the context of performance. A chant such as the Kyrie eleison, with a simple repetitive text, would be easy enough to follow; longer chants, especially hymns sung only once a year, would prove more difficult.

The earliest surviving sources of alternatim organ music date from the end of the fourteenth century. The Faenza Codex (early fifteenth century), includes versets for the Kyrie and Gloria, and five sets of versets for the Magnificat. Although there is a paucity of sources for the fifteenth century, the stature of the music published by Marco Antonio Cavazzoni (c. 1485-post 1569) in the early sixteenth century demonstrates to at least one scholar that there had been "a remarkable development" in Italian organ composition in the interim ([10], p. 149). Cavazzoni’s work first appears in the earliest printed volume of Italian organ music (an anonymous collection of keyboard arrangements of songs), published in Rome in 1517 [11]. In 1523, his own collection of secular and sacred pieces appeared in print [12]. Pope Adrian VI commended this book as a most agreeable way to learn to praise God with the organ. ${ }^{3}$ Cavazzoni's son Girolamo (c. 1525-post 1577), the more celebrated composer, published three "organ masses" in the 1540s (sets of versets for the whole mass) as well as Magnificats and hymns in alternatim [13]. Similar sets of masses were composed by Claudio Merulo, Andrea Gabrieli and others [14].

The principle behind alternatim could even be extended to the point where whole chants were played on the organ alone. For example, it was not uncommon for the organ to take full responsibility for the offertory chant, the Gloria in excelsis, and even the Creed. On solemn occasions, the organ would also accompany specific ritual actions such as entrances and exits. It is possible that many of the otherwise unspecified pieces in these collections (e.g., numerous "ricercars") would have been used in this way. The organ also provided music for the "elevation," the moment at mass when the consecrated bread and wine, now the body and blood of Christ, were raised by the priest to be adored by the people.

The music published by Cavazzoni and others would provide only a fraction of what was needed for the annual cycle of Sunday and festal services. The majority of the music would have been improvised by the organist, making more or less use of the chant melodies as a basis, perhaps using the published settings as models to be imitated ([15], p. 140). Music adapted from secular sources was clearly used, judging by criticisms this practice received ([16], p. 233). ${ }^{4}$

By the early sixteenth century, then, the liturgical use of the organ on Sundays and feast days was well-established; much of its use was in alternatim, most often improvised; organists made use of chant melodies and psalm tones, but also drew on secular melodies.

2 This was less functionally important for canticles (such as the Magnificat) and psalms which would normally be framed by an antiphon, which would establish the mode for the chants that followed. In practice, on solemn days antiphons might be played on the organ (see below).

3 “[...] quo commodius homines Deum in organis laudare discere possint” ([12], p. 78).

4 Banchieri's L'Organo suonarino of 1605 may represent a slightly later practice but is nonetheless instructive in its assumptions in this regard, see [17], pp. 56-61. 


\section{Cajetan}

There are passing remarks on music, instruments, and singing scattered throughout Cajetan's works. Extended remarks on the organ can be found in two places: the first is his commentary on the Summa Theologiae of Thomas Aquinas, in the portion written between the end of December 1511 and February 1517 ([5], vol. IX, pp. 296-97). The second is his Summula Peccatorum, an alphabetic manual providing advice for priests on almost every conceivable sin from A to Z, completed in 1523 [18]. The remarks on organ playing, as with many other sections in the Summula, are recycled from material in Cajetan's earlier work: in fewer than 350 words, the section in the Summula restates the main arguments and conclusions that the Summa commentary developed in over 1200 words. In both sources, Cajetan's purpose is a pastoral one, to guide priests in the care of souls and to help them deal with cases of conscience. It is possible therefore to read Cajetan's comments as a guide to the sins of musicians [19]. In this article, I will be focusing on the theological and musicological underpinning that supports the moral guidelines.

The text of Aquinas that occasions Cajetan's remarks in the Summa commentary concerns the praise of God (II-II, 91, 1-2): ${ }^{5}$ Whether God should be praised aloud, and whether God should be praised aloud with singing ([5], IX, pp. 294-96; [20], pp. 162-67). Aquinas answers in the affirmative in both cases. Cajetan begins his remarks by reiterating the foundation on which Aquinas presents his case: exterior acts of religion (such a preaching, singing, gestures) are all intended to serve the interior acts of devotion and prayer. Singers do not sing "directly" to God, but sing in order to arouse their own interior devotion and the devotion of others. It is this interior devotion which is directed to God. For Cajetan, the use of music in worship can only be justified insofar as it performs this task: to employ music in worship as if it were directly beneficial to God is to miss the point; to employ music in worship for the delight or pleasure of those who hear it (as distinct from their devotion) it is to lead them into temptation.

Looking to Augustine, Aquinas sees music in worship as a concession: he concluded that music was profitably introduced into divine worship so that the "souls of the faint-hearted may be more incited to devotion” (II-II, 91, 2, resp.; [20], p. 166). However, he draws the line at musical instruments. According to Aristotle, instruments move the soul to pleasure rather than fostering good interior dispositions. They are therefore to be excluded from worship. Aquinas claims that instruments were only permitted in Old Testament worship because the people were so hard and carnal ("durus et carnalis") that they needed such means to arouse their devotion.

In his commentary on this passage, Cajetan says nothing about singing and its use in worship; and while he reiterates Aquinas's point about devotion, the bulk of his comments are directed to a new question, not dealt with by Aquinas, concerning the organ. Times have changed: Aquinas did not deal with the use of the organ in worship because, says Cajetan (erroneously), the Church did not use organs in Aquinas's day —and this remains the case in papal liturgies. In addition, while he agrees that an attentive reading of Aquinas's argument would still, strictly speaking, exclude organs from worship, Cajetan pleads for tolerance: since people have grown so distant from divine worship, the use of

\footnotetext{
The Summa Theologiae is cited part, question, article (and, where necessary, objection, response, etc).
} 
organs in worship might attract them to participate. ${ }^{6}$ His enthusiasm is muted, however: this medicine should not be used in such a way that it does harm to the healthy or diminishes their devotion. He clearly wonders whether the good it brings justifies the risks. In the Summula, he is more pithy: although it is a new practice, it is permissible for the fleshly and the imperfect. ${ }^{7}$ In other words, Cajetan uses the same scheme of thought as Aquinas, but he makes more concessions, extending the boundary line to admit the organ. However, it is still a boundary line.

The rest of his remarks concern what remains beyond the boundary, i.e., musical practices that are not to be admitted into divine worship. He asks: may organists play "secular vanities" during divine worship? In reply he notes opposing points of view: at one extreme, some say that it is always irreverent to do so and is therefore always mortally sinful. Cajetan finds this position too absolute, remarking that not every failing in church music constitutes a mortal sin. At the other extreme, he notes the view of those who argue that music has no meaning of its own: the same tune can be used in a vain purpose by one person and a spiritual purpose by someone else; or a melody can be sung to a wicked text by one person and a spiritual text by another. Cajetan rejects this extreme position with the claim that there can never be complete abstraction of meaning such that any and all musical sounds could be admitted into worship. ${ }^{8}$ Here he alludes to a text from Jerome cited by Aquinas: Jerome lambasts those who "make the church resound with theatrical measures and airs" (II-II, 91, 2, obj. 2; [20], p. 165). For Cajetan, some kinds of music are so marked by their associations that they cannot be "refitted" and made suitable for use in worship. ${ }^{9}$ In this context, Cajetan explicitly mentions songs on worldly or amorous themes; we might assume that his list would also include music used for dancing, hunting, or battle. If these melodies are played on the organ during divine worship, minds may be distracted to vain things, even to unchaste thoughts. Furthermore, since the playing of the organ is a part of the divine worship itself (not an adjunct, or peripheral activity), what the organ offers is offered in the name of the whole Church; therefore, it must offer only what is fitting.

Unlike Plato, who banished specific musical modes from his ideal Republic because they fostered the wrong kind of behavior, Cajetan does not offer an argument based on the intrinsic character of the music itself. Indeed, insofar as this Platonic/Pythagorean tradition is preserved in Aquinas, Cajetan ignores it. His concern is not with the cosmic or psychic resonance of the music as such, but with the meaning it brings with it: What does it say? What would it mean if it were expressed in words? ${ }^{10}$ And this meaning is generated not through "purely" musical structures but through extrinsic associations. Cajetan would seem to agree with musicologist Nicholas Cook, that "pure music" is a fiction. "The real thing unites itself promiscuously with any other media that are available” ([21], p. 92): the

6 “[...] propter nimiam elongationem hominum a divino cultu, ut vel sic allecti divinis intersint” ([5], IX, p. 296a).

“[...] licitus tamen est pro carnalibus adhuc fidelibus et imperfectis” ([18], p. 437).

8 “Ad evidentiam huius, oportet vitare ambo extrema. Ne scilicet tanti faciamus abstractionem soni a materia ut omnis sonus aeque admitti dignus sit in ecclesia” ([5], IX, p. 296a).

9 “[...] ratione usus vel eventus potest ibi esse peccatum. Ratione usu, si accommodatus communiter est talis sonus ad materiam dedecentem sacra: quoniam idem est de tali sono iudicum quod est de cantu theatrali aut tragoedico, qui propter talem usum prohibiti sunt in ecclesia. Ratione vero eventus, si communiter ex tali sono excitantur auditorum animi ad mala vel vana” ([5], IX, 297b).

10 “A gravissimo tamen peccato, et forte mortali sacrilegii, non excusatur qui ex intentione inter divina immiscet talia mundana quae, si verbis exprimeret ibidem, nullus excusaret a mortali” ([5], IX, p. 297a). 
"meaning” of a melody or harmonic progression or rhythm emerges from a history of interaction with lyrics, instruments, theatres, taverns, and so on. Even if the organist is well-intentioned and the music is chosen solely on account of its musical virtue, ${ }^{11}$ and seeming adaptability to worship in itself, the unsuitable associations still disqualify it. As a last resort, Cajetan appeals to the law, noting that the text of Jerome cited by Aquinas had found its way into canon law: therefore, since secular songs are banned from worship, so, by extension, are secular melodies [22].

This provides the first answer to the question of this paper, an answer in the affirmative: solo organ music is indeed capable of conveying a particular meaning or text. There is a palpable concern that the associations of secular music are so powerfully eloquent that they cannot be overcome or redirected by a new context (i.e., worship of God): the risk of distraction, irreverence, and sacrilege remains too great.

\section{Dominicans}

Cajetan's comments discussed so far were not the work of a private scholar but a public theologian - a senior member of his order and an adviser to popes. The matters he dealt with in his Summa commentary and Summula were repeatedly addressed by the Dominicans when they came together to set the direction for their order in General Chapters. The rulings of these Chapters provide occasional but consistent attention to musical matters.

At the beginning of the sixteenth century, there is a repeated stress on standardization and decorum. The Chapter of 1501 (Rome) required the singing of the divine office to be distinct and devout, as well as brief and succinct. The brethren are reminded that their tradition is to sing without extensive melismas and other vocal elaborations. This section concludes with a flourish: When the divine office is meant to be sung and can be sung, then let it be sung ([23], p. 4). According to the Chapter of 1505 (Milan), in public worship, the tone is to be set by the officiating minister, who begins the office slowly, with devotion and maturity, and a moderated voice. Once again, the brethren are instructed to sing in a distinct manner, respecting the pauses between lines, not prolonging the final notes of phrases, with each verse following on just as the previous one finishes ([23], p. 28). These two chapters promote a simple, uncluttered liturgy, with all texts clearly and distinctly enunciated.

The matter of alternatim is taken up explicitly at the General Chapter of 1515, held in Naples, during Cajetan's generalate. The Chapter briefly sets out regulations for those convents where the organ is played ([23], p. 136). The first regulation prohibits the playing of secular vanities. The reason is that the organ is now ("hodie") part of the solemnity of divine worship; to admit anything profane or vain is to commit the sin of superstition (i.e., worshipping God but improperly). In addition, since the singing of secular songs in church is clearly prohibited, so must the playing of secular music also be prohibited — even if they both are refitted with a sacred theme. ${ }^{12}$ The formulation of this regulation is very reminiscent of Cajetan's Summa commentary examined above. As was noted there, Cajetan composed his commentary on this part of Aquinas's Summa between 1512 and 1517. There are 189 questions in this part, and the music question, number 91, is about halfway through. Cajetan was occupied with many concerns at this time (including the Fifth Lateran Council, 1512-1517), so his work rate on the commentary may not have been steady; nevertheless, he may well have been working

11 “[...] ex sola intentione soni talis propter suam consonantiam” ([5], IX, p. 297b).
12 “[...] licet utrumque possit ad sacram applicari materiam” ([23], p. 136). 
on this part of the commentary around the time of the Chapter. Without further detailed investigation, we can only speculate which came first, the Summa commentary or the Chapter regulations. In any case, with this first point, the Chapter concurs with Cajetan's affirmative answer to our question: solo organ music is indeed capable of conveying a particular text, in this case, the original meaning of secular songs. For this reason, secular music may not be played and cannot be made playable on the organ in worship.

However, the Chapter takes up a less certain position with three further regulations, each of which establishes a new discipline in choir. First, if in alternatim performance, the verset played by the organist is one during which the friars would normally bow (such as the "Gloria Patri" at the end of every psalm and canticle — see verset 11 of the Magnificat, above), then the cantor shall speak the text aloud slowly, thus providing an effective cue for all to bow together. ${ }^{13}$ Second, when an antiphon is to be played on the organ, the text is to be recited by the cantor, again in a clear, deliberate voice, on behalf of the whole choir, so that all hear it calmly together. ${ }^{14}$ And third, when a hymn or canticle commences with an organ verset (as was customary), the cantor is nevertheless to begin the first line of that verset before the organ proceeds. This is so that the people understand the song that is beginning, and that their devotion may be thereby aroused. ${ }^{15}$ In this instance, "the people" refers not to the friars themselves in the choir stalls, but the congregation in the nave, in attendance for a major service on a Sunday or feast day.

These new disciplines serve as remedies to an implied lack of textual clarity in the organ versets. Since the instrumental music does not speak audibly enough, it must be complemented by the more articulate human voice. This is rather like a musical equivalent of a technique used in silent film: to complete the viewers' understanding of a silent movie, panels of text are provided to convey elements of the storyline (known as "narrative intertitles") and elements of dialogue, which viewers can see being spoken, but cannot hear (“dialogue intertitles”) [24]. These Dominican regulations create something like dialogue intertitles, projecting the verbal text that listeners know is being performed by the organ but which they cannot actually hear or understand.

Furthermore, the final regulation amounts to a small but significant additional adjustment: as was noted above, the organ usually took the first verse, in order to establish the pitch and mode for the singers; this new regulation asks that the cantor sing the usual intonation, in order to indicate the text that is to be sung. Only then will the organ continue with the first verset. In this way, a practical musical benefit, designed to facilitate the steady flow of liturgical rhythm, is sacrificed for the “dialogue intertitle” designed to foster greater intelligibility and therefore greater devotion.

With these three regulations, the Chapter gives a somewhat different answer to our question: solo organ music might be capable of conveying a particular text, but not sufficiently to ensure the required coordination of gesture in choir, nor to enable understanding among the people in attendance. Because the organ alone cannot be relied upon to enunciate the assigned text, a human voice is required to supply what is now understood as the "missing" text. The invention of intertitles, during

\footnotetext{
13 “[...] cantor sine nota, alta voce et morose dicat illa, et dum a cantore dicuntur, omnes inclinent; et hoc ut simul et uniformiter fiant inclinationes ab omnibus” ([23], p. 136).

14 “[...] cantor alta voce et morose illud dicat in persona totius chori, et hoc ut quietius omnes simul audient” ([23], p. 136).

15 “[...] et hoc pro devotione populi, ut intelligens, quod inchoatur, assurgat” ([23], p. 136).
} 
the period of Cajetan's leadership of the Dominican order, demonstrates two things: that instrumental music was being judged according to its rhetorical precision, and that it was found wanting.

Subsequent General Chapters refine the regulations for the practice of alternatim, but always along the same lines. In 1523, the Valladolid Chapter ruled that the Creed must always be sung in its entirety; it may never be played alone by the organ or in alternatim, however solemn the occasion. Why is the Creed singled out in this way? According to the Chapter: so that the faith, which should be professed openly and preached to the people, may not be concealed under the playing of organs. ${ }^{16}$ This is the clearest statement yet of the insufficiencies of the organ: its music hides or obscures the text for which it is responsible. The same 1523 Chapter also ruled that the Gloria in excelsis should not be played entirely by the organ when the people are in attendance. Preferably it should be sung by the choir, or at least performed in alternatim. The Gloria in excelsis and the Creed would be used on Sundays and major feast days throughout the year; other regulations relate to chants that occur perhaps only once or twice in the church's year and whose texts would therefore be less well-known. The chapter insists on a reduced role for the organ: in the case of sequences (hymns attached to specific days in the calendar), these must be entirely sung. In the case of antiphons (the cycle of scripture verses that frame canticles such as the Magnificat), these must also be sung throughout, with one exception: on those solemn occasions when the antiphon is repeated before and after the canticle, one of the iterations, but only one, may be assigned to the organ ([23], p. 184). In other words, all of the less familiar text must be sung aloud.

At the Chapter of Lyons in 1536, the restrictions on the Gloria in excelsis are further tightened: while again banning the complete performance of the chant by the organ alone, the Chapter also requires that, if it is to be sung alternatim, then intertitles are to be provided - the organ's versets are to be supplied aloud by one of the brethren in a distinct and intelligible voice so that all in choir can hear. ${ }^{17}$ There are two things to note here: first, the concern is no longer simply with the people, but with the choir, the friars themselves, hearing the full text. Second, the Gloria in excelsis is sung at almost every Sunday and feast day Mass and so would be much more familiar than sequences and antiphons. However, so weak is the eloquence of the organ that even here intertitles are deemed essential.

The singing of the Creed in its entirety, without any playing of the organ, is reaffirmed by General Chapter in 1542 and 1546 (both Rome), in 1551 (Salamanca), in 1561 (Avignon) and 1574 (Barcelona) ([23], pp. 294, 306, 323; [25], pp. 33, 171). The reason for the repetition seems to be that the regulation was ignored: the organ masses of Girolamo Cavazzoni (1543), and Claudio Merulo (1568) mentioned above, were not alone in providing music for the alternatim performance of the Creed; alternatim settings of the Creed only disappear in the early seventeenth century ([16], p. 233).

By the middle of the sixteenth century, Dominican thinking on instrumental liturgical music is clear: the priority is verbal intelligibility (which fosters devotion), and any practice that obscures this goal is to be curtailed or severely restricted. The trajectory shows an increasing anxiety that memory, context, ritual, and routine cannot fill the lacuna caused by organ alternatim: the words themselves must be enunciated out loud.

16 “[...] ne fidem quam profiteri palam tenemur et populo praedicare, sub modulis organorum videamur occultari” ([23], p. 184).

17 "Versiculus vero organi ab uno frater distincte et intelligibiliter audiente choro dicatur” ([23], p. 261). 
Musical issues were discussed at the Council of Trent (1545-1563), including the use of secular music, and music that obscured text, but the decrees of the Council contain very little of detail. As Craig Monson has shown, the Council of Trent "offered a structural impetus in an ongoing process of renewal and reform, in which music was also swept along, but with minimal specific directives” ([26], p. 403; also [27]). The specific directives of the Dominicans seemed to have been in step with the general trend, as can be seen from the Caerimoniale Episcoporum, issued in 1600 as part of the revision of liturgical books mandated at Trent [28]. This book contains the liturgical norms for the services presided at by a bishop. It therefore proposes a style of liturgy that meets the dignity of the office but which also might serve as a model for other acts of worship. In a section on the use of the organ, the Caerimoniale echoes all of the principles mentioned thus far, enshrining them in a form now applicable throughout the Catholic Church. Regarding what I have been calling intertitles, it takes two further steps. First, where there are gestures to be coordinated (for example, during the final doxology verses of hymns, where a bow is customary), then these versets are simply reassigned to the choir, even if the choir has sung the previous verset (as in the example of the Magnificat, above, where all bow during verset 11). In other words, rather than buttress the organ's inadequate articulation with an intertitle (as the Dominicans had proposed as early as 1515), that verset is simply taken from the organ and assigned wholly to singers. This makes the cue for the collective gesture much clearer, not least because it would align with the practice used at the daily round of liturgies when the organ was not played. Second, the Caerimoniale not only recommends a blanket use of intertitles in all instances of alternatim, but says that it would be praiseworthy if a cantor, in a clear voice, sings the text along with the organ. ${ }^{18}$ Here the trajectory seen in the Dominican legislation reaches a resting place, and the outcome is something musically and liturgically quite different from organ alternatim. The organ continues to add solemnity to worship, but we no longer find any trace of the idea that the organ alone can be trusted with text. Instead, the organ is deemed incapable of presenting the text in any acceptable way; it must be supplemented, not only by a spoken intertitle to articulate what is partially hidden, but by a more complete and verbal musicality: instrumental music has undergone a redemptive transformation into vocal music; Higginbottom rightly concludes that this practice "undermines the very notion of alternatim organ music” ([15], p. 141).

\section{The Singing Organ?}

I have presented an overview of positions taken regarding liturgical organ music by Cajetan and his Dominican confreres in the first part of the sixteenth century. Stepping back from the detail, I would like to offer a couple of reflections.

\subsection{Wordless Music and Words}

In 1576, Dominican friar Juan de Palencia published a new edition of his order's Ordinarium, the book describing liturgical ceremonies [29]. Although he offers explanatory annotations on some of

18 “[...] sed advertendum erit, ut, quandocumque per organum figuratur aliquid cantari, seu responderi alternatim versiculis hymnorum, aut canticorum, ab aliquo de choro intelligibili voce pronuntietur id, quod ab organo respondendum est. Et laudabile esset, ut aliquis cantor coniunctum cum organo voce clara idem cantaret” ([28], pp. 51-52). 
rubrics, he makes no claims for innovation in this work, but states that these are the opinions of the "older Fathers" ([30], p. 282). Juan mentions the regulations concerning the organ given by the various General Chapters and remarks that though the use of the organ in church is a new thing ("nova res"), it is now found in all churches. This is for two reasons: to give the choir some relief, and to add greater solemnity to worship. ${ }^{19}$ However, as we have seen, by Juan's day, the organ was actually expected to do more than this: it was expected to sing words - and not just a few general ideas, but around half of the words that would otherwise be sung by the choir and the people. Early in the sixteenth century, the organ's role began to be seen almost exclusively in logocentric terms, standing or falling on the basis of its ability to convey text. Sixteenth-century churchmen reasoned that, if the people do not understand what is being sung (whether by the organ, or by voices in polyphony), then their devotion suffers. Once the paradigm of verbal intelligibility was established, it is no wonder that organ alternatim was viewed as inadequate (as also were vocal polyphony and melismatic chant). In addition, what of the Latin language? Surely that too was an obstacle to intelligibility and therefore to devotion? Cajetan had already aired these more radical possibilities in his 1528 commentary on Paul's First Letter to the Corinthians. Echoing Erasmus, he claims Paul's authority for the use of the vernacular in worship: where prayers are said publicly, in the hearing of the people, it would contribute more to the building up of the Church if they were said in the language common to all. ${ }^{20}$ And when Paul says that he would rather speak five words "with his mind" (i.e., intelligibly) than ten thousand words in tongues, Cajetan uses the occasion to complain about those kinds of music where text is assigned to the organ, or is obscured by the music of many voices. On balance, he says that it would be better to have no music at all than to have an unintelligible cacophony. ${ }^{21}$

Aquinas had shown a little more latitude: he noted that when singers sing a sacred text with devotion, they are stirred to further devotion by the "hidden correspondences" between the music and the affections of their spirit. It is as if the text harnesses the potential in the music to arouse greater devotion within them. In addition, even though the people might not understand what the singers are singing, if they understand that it is sung with devotion, then their devotion is aroused in turn (II-II, 91, 2, ad 5; [20], p. 167). Aquinas certainly appreciates the importance of text in worship. However, he also recognizes the power of music itself to act on the spirit, in the context of worship, even where words are obscured.

19 "Sed iam in omnibus ecclesiis habentur ad levamen chori et maiorem solemnitatem divini officii” ([29], p. 128).

20 On 1 Cor 14.17: "Ex hac Pauli doctrina habetur quod melius ad aedificationem ecclesiae est orationes publicas quae audiente populo dicuntur, dici lingua communi clericis et populo, quam dici latine” ([31], p. 137a). Wegman provides the original and an English translation of Erasmus's annotation on the same passage, which Cajetan knew ([2], pp. 161-65).

21 On 1 Cor 14.19: "Unde discere debemus eligibilius esse ut in Ecclesia dicantur divina (horae scilicet canonicae et Missae) intelligibiliter sine melodia musica, quam sic ut non intelligi possint, qualiter sunt tam particulae quae sonis commituntur organorum, quam quas cantus reddit imperceptibiles, vel multitudine clamoris occupantis, vel qualitate cantus notas magis, quam verba concinentis. Haec enim omnia magis extranea sunt quam decem millia verborum in lingua” ([31], p. 137a-b). 


\subsection{Wordless Music and Worldly Music}

As noted above, the sources I have been examining actually provide two conflicting answers to the question of meaning in solo organ music. On the one hand, Cajetan and the Dominican Chapters are clear that secular melodies inevitably carry with them the echo of their texts and/or earlier usage and so will subvert the devout participation of worshippers. For this reason, secular songs are excluded from worship by law, and by extension, so are secular melodies - in other words, when playing a secular melody or rhythm, the organ cannot help but sing the secular song. On the other hand, when sacred melodies are played on the organ, they cannot be relied on to convey their assigned liturgical texts effectively enough to ensure the devout participation of worshippers. For this reason, various tactics are proposed to remedy the inarticulateness of the organ, or replace it all together-in other words, the organ cannot sing the sacred song clearly enough. The expectations are both inconsistent and unequal: the churchmen wanted to exclude every trace of secular distraction from worship, however fleeting, but they wanted the full content of the sacred texts to be realized in the act of worship. From the secular melodies, they feared even a minimum of provocation to lascivious thoughts; from the sacred melodies they expected a maximum of meaning arousing devotion. ${ }^{22}$

As we saw above, the Dominicans' determined ban of secular music is not based on purely musical qualities, but on the associations a piece of music brings with it. Such an extrinsic point of view might have yielded a less absolute judgement on secular melody: since the essential properties of musical modes do not change very much over time, clear and abiding directives could be given concerning certain modes and certain rhythms. However, the extrinsic associations of a melody can and do change; if associations can be acquired, they can be lost too. The frottole of Bartolomeo Tromboncino, adapted for organ solo and published in 1517, may have scandalized or titillated churchgoers in the 1520s (had they been played in church), but by the 1820s few people would be able to recall their texts, or even feel in their rhythms the traces of carnal desire. For this reason, one might imagine the Dominicans adjusting their judgment from an absolute ban to a conditional ban, depending on the likelihood of the associations enduring. However, this is not forthcoming: instrumental music remains a weak point, a back door, which must always be guarded lest the world and the flesh find an easy way in. Such a view would struggle to accommodate evidence that venerable elements of the sacred rites had in fact made their way into worship from "outside"—-such as the phrase "Kyrie eleison," ("Lord have mercy") which "is not originally a Christian prayer at all but rather an acclamation employed in pagan worship, adopted in the cult of the Roman emperor” ([32], p. 335).

22 This is not the only issue on which these reformers were inconsistent: the sources examined in this article do not question the practice of reciting parts of the Mass silently, particularly the central Eucharistic Prayer, or Canon of the Mass. For centuries it had been the custom for this prayer to be said out of the hearing of the people, and this custom is reaffirmed by General Chapter (Salamanca, 1551, [23], p. 321, and Rome 1569, despite practice to the contrary, [25], p. 90), as well as by the Council of Trent (Decree on the Sacrifice of the Mass, 1562). This is another sign that these reformers were not solely concerned with verbal audibility and intelligibility. 


\section{Conclusions}

The implication of this study is that organ alternatim did not fall out of favor because it failed to carry out the job it was given in the fourteenth and fifteenth centuries, but because it could not do the new job is was given in the sixteenth century. Organ alternatim made sense in a world that included gothic architecture, stained glass, symbolic vestments and gestures ([15], p. 133; [33], pp. 82-83, 132-33). Under the influence of renaissance humanism, its job-description changed. ${ }^{23}$ In summary, there are four things we can say about the sixteenth-century Dominicans and their judgement on the liturgical use of the organ. First, they accepted it. This sets them apart from Aquinas, who believed that instruments were not apt for use in worship, "for fear of seeming to imitate the Jews" (II-II, 91, 2, obj. 4; [20], p. 165). Second, they restated a centuries-old aversion to secular music in worship, but did so with a more intense protectiveness of the purity of worship. It is as though the organ is a Trojan horse that might conceal within its belly a host of distractions and worldly temptations. Third, when trying to grasp the "meaning" of organ music, they did not employ the essentialism of the Platonic-Pythagorean tradition, but assumed a more extrinsic view: that the meaning of a melody or rhythm is determined by the associations it brings with it, its familiar lyrics and former uses. This shifts the focus somewhat from the music in itself to the music as it is known by listeners, and it makes music's meaning unpredictable and fluid. Fourth, in the light of this indeterminacy, the Dominicans sought to police the meaning of organ music by requiring that it be hand-cuffed to text-by the remedial use of what I have called dialogue intertitles. As I said at the outset, the focus of this paper is a particular way of thinking about organ music, not the actual and varied practices of organists. The extent to which performance practice was actually modified in the light of these instructions is beyond the scope of this study. Nevertheless, the repetition of certain instructions, and the evidence of published sources, suggest that a stubborn gap remained between the ideal, enshrined in laws and exhortations, and the practice.

This cluster of ideas finds echoes today: organ alternatim has modern heirs in the practice of organists to improvise on well-known hymn tunes, or of instrumental ensembles to continue playing variations on a song after all the verses have been sung. The concessions also continue: certain electronic and percussion instruments are used to draw young people into church who would, it is argued, otherwise stay away. The tactic I have described as intertitles also endures, in various contexts: at Anglican Evensong, the officiant will introduce the choral anthem by title and composer, and read at least the first few lines of its text, especially if it is to be sung in Latin; in many churches, printed worship aids are provided with all the words of the service, to aid participation; and the organ blessing cited at the beginning of this article gives the clearest example of instrumental music being charged with conveying verbal meaning. All such announcements, titles, and explanations have to be handled with great care if they are not to break the ritual flow or capsize the liturgy ([38], pp. 152-53).

For most critics of organ alternatim, and instrumental music more generally, its crime is that it obscures the words. Defenders of instrumental music seldom rebut this accusation: judged on the criterion of verbal intelligibility, instrumental music will always fall short. Instead, instrumental music

23 For relevant discussion and theological analysis of the broader context, see [34], especially chapter 2. For modern discussions of musical meaning, see [35,36], and [37], chapter 3. 
is defended for its own non-verbal eloquence, a properly musical eloquence, which is able to offer something that complements verbal intelligibility: sonorous beauty, ritual solemnity, emotional appeal, and its own unique means of shaping a disparate crowd of people into a worshipping assembly.

\section{Acknowledgements}

I am very grateful to two undergraduate researchers, Stefania Lista and Eli McNeil, for their genial and competent collaboration on this project.

\section{Conflicts of Interest}

The author declares no conflict of interest.

\section{References and Notes}

1. Catholic Church. Livre Des Bénédictions: Rituel Romain. Paris: Chalet-Tandy, 1988.

2. Wegman, Rob C. The Crisis of Music in Early Modern Europe, 1470-1530. New York: Routledge, 2005.

3. Cajetan, Tommaso de Vio, Jacques Almain, and John Major. Conciliarism and Papalism. Edited by J. H. Burns and Thomas M. Izbicki. Cambridge Texts in the History of Political Thought. Cambridge: Cambridge University Press, 1997.

4. Wicks, Jared. "Roman Reactions to Luther: The First Year (1518).” Catholic Historical Review 69 (1983): 521-62.

5. Aquinas, Thomas. Summa Theologiae cum commentariis Thomae De Vio Caietani Ordinis Praedicatorum, Opera omnia. vols. IV-XII (Rome, 1888-1906).

6. O’Connor, Michael. “A Neglected Facet of Cardinal Cajetan: Biblical Reform in High Renaissance Rome.” In The Bible in the Renaissance. Edited by Richard Griffiths. St Andrews Studies in Reformation History. Aldershot: Ashgate, 2001, 71-94.

7. Forte, Stephen L. The Cardinal-Protector of the Dominican Order. Rome: S. Sabina, 1959.

8. Berry, Mary. "Dominican Friars." Grove Music Online. Available online http://www.oxfordmusiconline.com.myaccess.library.utoronto.ca/subscriber/article/grove/music/0 7970 (accessed on 8 June 2014.).

9. Mother Thomas More [Mary Berry]. “The Practice of Alternatim: Organ-Playing and Polyphony in the Fifteenth and Sixteenth Centuries, with Special Reference to the Choir of Notre-Dame de Paris.” The Journal of Ecclesiastical History 18 (1967): 15-32.

10. Stembridge, Christopher. "Italian Organ Music to Frescobaldi." In The Cambridge Companion to the Organ. Edited by Nicholas Thistlethwaite and Geoffrey Webber. Cambridge: Cambridge University Press, 1999, 148-63.

11. Frottole Intabulate Da Sonare Organi. Libro Primo. Rome: Andrea Antico, 1517.

12. Cavazzoni, Marco Antonio. Recerchari Motetti Canzoni: Libro Primo (Venezia 1523); Recercada (Castell'Arquato, II): Con Riproduzioni Delle Fonti. Edited by Liuwe Tamminga. Latina: Il Levante Libreria Editrice, 2009.

13. Cavazzoni, Girolamo. Orgelwerke. Edited by Oscar Mischiati. Mainz: Schott, 1961. 
14. Higginbottom, Edward. “Organ Mass.” Grove Music Online. Available online: http://www.oxfordmusiconline.com.myaccess.library.utoronto.ca/subscriber/article/grove/music/2 0438 (accessed on 8 June 2014).

15. Higginbottom, Edward. "Organ Music and the Liturgy." In The Cambridge Companion to the Organ. Edited by Nicholas Thistlethwaite and Geoffrey Webber. Cambridge: Cambridge University Press, 1999, 130-47.

16. Judd, Robert. "Italy." In Keyboard Music Before 1700, 2nd ed. Edited by Alexander Silbiger. Routledge Studies in Musical Genres. Florence, KY: Routledge, 2003, 222-99.

17. Bonta, Stephen. "The Uses of the 'Sonata Da Chiesa." Journal of the American Musicological Society 22, no. 1 (1969): 54-84.

18. Cajetan, Tommaso de Vio. Summula (peccatorum) Caietani [...] perquàm docta, resoluta ac compendiosa de peccatis summula. Antwerp, 1575.

19. Blackburn, Bonnie J. "How to Sin in Music: Doctor Navarrus on Sixteenth-Century Singers." In Music as Social and Cultural Practice: Essays in Honor of Reinhard Strohm. Edited by Melania Bucciarelli and Berta Joncus. Woodbridge, Suffolk: Boydell Press, 2007, 86-102.

20. Aquinas, Thomas. Summa Theologica. Literally translated by Fathers of the English Dominican Province. London: Burns, Oates \& Washbourne, 1922, vol. XI.

21. Cook, Nicholas. Analyzing Musical Multimedia. New York: Oxford University Press, 1998.

22. Gratian's Decretum, Distinction 92 c. 1. Available online: http://geschichte.digitalesammlungen.de/decretum-gratiani/kapitel/dc_chapter_0_980 (accessed on 1 June 2014).

23. Reichert, Benedict Maria, ed. Acta Capitulorum Generalium Ordinis Praedicatorum, vol. IV. Monumenta Ordinis Praedicatorum Historiae, vol. IX. Rome, 1901.

24. Chisholm, Brad. "Reading Intertitles.” Journal of Popular Film and Television 15, no. 3 (1987): 137-42. doi:10.1080/01956051.1987.9944095.

25. Reichert, Benedict Maria, ed. Acta Capitulorum Generalium Ordinis Praedicatorum, vol. V. Monumenta Ordinis Praedicatorum Historiae, vol. X. Rome, 1901.

26. Monson, Craig A. "Renewal, Reform, and Reaction in Catholic Music.” In European Music, 1520-1640. Edited by James Haar. Studies in Medieval and Renaissance Music 5. Woodbridge, UK; Rochester, NY: Boydell Press, 2006, 401-21.

27. Monson, Craig A. "The Council of Trent Revisited." Journal of the American Musicological Society 55, no. 1 (2002): 1-37.

28. Ceremoniale Episcoporum jussu Clementis VIII. Pont. Max. Roma, 1600.

29. De Palencia, Juan, ed. Ordinarium Sacrarum Caeremoniarum, et Diuini Officii, Ad Ritum Fratrum Praedicatorum. Salamanca, 1576. Available online: http://www.cervantesvirtual.com/ obra/ordinarium-sacrarum-caeremoniarum-et-diuini-officii-ad-ritum-fratrum-praedicatorum/ (accessed on 1 June 2014).

30. Bonniwell, William R. A History of the Dominican Liturgy. New York: J.F. Wagner, 1944.

31. Cajetan, Tommaso de Vio. Opera Omnia Quotquot in Sacrae Scripturae Expositionem Reperiuntur. Lyons: Prost, 1639, vol. 5.

32. Baldovin, John F. "Kyrie Eleison and the Entrance Rite of the Roman Eucharist.” Worship 60, no. 4 (1986): 334-47. 
33. Fassler, Margot Elsbeth. Music in the Medieval West. Western Music in Context: A Norton History. New York: W. W. Norton \& Company, 2014.

34. Begbie, Jeremy. Music, Modernity, and God: Essays in Listening. Oxford: Oxford University Press, 2014.

35. Davies, Stephen. Musical Meaning and Expression. Ithaca: Cornell University Press, 1994.

36. Robinson, Jenefer. Music and Meaning. Ithaca: Cornell University Press, 1997.

37. Swain, Joseph P. Musical Languages. New York: W. W. Norton \& Company, 1997.

38. Baldovin, John F. Reforming the Liturgy: A Response to the Critics. Collegeville: Liturgical Press, 2008.

(C) 2014 by the author; licensee MDPI, Basel, Switzerland. This article is an open access article distributed under the terms and conditions of the Creative Commons Attribution license (http://creativecommons.org/licenses/by/3.0/). 